\title{
Terror Attacks and the Production of the Sacred
}

\author{
Thomas Clavel \\ Certified teacher of Modern Literature, Seine-Saint Denis (France)
}

\begin{abstract}
Starting from René Girard and Philippe Muray's thoughts on terrorism, the present paper introduces the bypothesis that the re-sacralization of the byperfestive 1 era is the unexpected but seemingly inevitable effect of jihadist attacks in Europe. These assumptions aim to shed new light on the Western rhetoric of commemorative events and media discourses.
\end{abstract}

\section{Keywords}

Islamism; Jihadism; Suicide attack; sacrifice; mimetic theory; hyperfestivism; René Girard; Philippe Muray.

To not delude ourselves, neither concerning the target (we, Westerners) nor concerning the attackers (the Islamists), and to state that the alterity (of the attackers) will not eternally remain radical, that it is even no longer radical, seemed to me the least of things. This is what has been little, or badly, understood. ${ }^{2}$

$$
\text { Philippe Muray }
$$

\section{Introduction}

In November 2001, René Girard stated that terrorism "lies in an exacerbated desire for convergence and resemblance" 3 with respect to the Western world. Far from consolidating the everlasting stereotype of a warlike Islamism allegedly impervious to our contemporary model of society, the French anthropologist preferred to reflect on the relation between

\footnotetext{
1 "Hyperfestif", "Festivisme", "Homo festivus" are neologisms created by the French author Philippe Muray. For the present translation, we kept these words as they are and just slightly adapted them to the English language. The meaning of these expressions is explained later in the footnotes.

2 Philippe Muray, Essais (Paris: Les Belles Lettres, 2015), 1688.

3 René Girard, Henri Tincq. "What is Occuring Today Is a Mimetic Rivalry on a Planetary scale", initially published in Le Monde (November 6, 2001). An English translation by Jim Williams for $C O \& V R$ is available via the following link:

https://www.uibk.ac.at/theol/cover/girard/le_monde_interview.html (accessed August 16, 2017).

This is an Open Access article distributed in accordance with the Creative Commons Attribution Non Commercial (CC-BY-NC-ND 4.0) license, which permits others to copy or share the article, provided original work is properly cited and that this is not done for commercial purposes. Users may not remix, transform, or build upon the material and may not distribute the modified material (bttp:/ / creativecommons.org/licenses/by-nc/4.0/)
} 
Jihad and West within the categories of "competition" rather than "difference."4 Having planted the seeds of their warrior ideology in our own civilization's soil, nourished by resentment, torn between the two complementary forces of attraction and repulsion, our enemies resemble us more than we think: we are both playing our parts on the common ground of mimetic rivalry. Fascinated by what the westerners desire, Jihadists thus want to deprive them of it (destruction being, as Sade taught us, the highest level of ownership and possession). Basically, warrior Islamism is nothing but Islam's mimetic reaction which is its most contemporary deviance.

But if the terrorists seek to destroy what westerners desire, the dialectic of rivalry also, naturally, works in the opposite direction: westerners come to desire what the terrorists destroy. Indeed, the European man begins to more strongly covet the object that the bloodthirsty enemy aims to deprive him of until his own death. He claims for everything that the kamikaze made sacred through his own sacrifice and through the sacrifice of innocent victims. Suddenly, a pop concert gets a superior meaning; drinking a beer on the terrace becomes an act of high resistance; the fireworks of July 14 are tinged with more profound colours; a French satirical journal nearly falling into the dustbin of history ${ }^{5}$ resurrects to such an extent that it becomes the Breviary of an entire generation.

In brief, if Islamic terrorism generates violence, violence also generates reciprocal religious effects in return. Through the blood that they spilled, the terror attacks sanctified paltry caricatures that passers-by do not even consider, they have celebrated the most banal coffee houses, ennobled the most trivial band singers, shed light on the most obscure rock bands - generating a sudden and fictitious solidarity between consumers and creating some simulacra of religious communion. Through a diabolical pirouette, terrorists became the most ruthless allies to the society of the spectacle, consecrating the vivre-ensemble ${ }^{6}$ and festivism ${ }^{7}$ as superior dogmas whose hashtags and Je suis are now equivalent to unavoidable psalms.

Likewise, several phrases, shared by all the people interviewed by the mass media during a testimony or a commemoration, are now commonplace. Better still: they form the Credo of

\footnotetext{
${ }^{4}$ Ibid. In an interview for the French journal La Croix, René Girard describes Osama bin Laden as a "modern man influenced by western values". See René Girard, «Que Valent nos Valeurs? ", La Croix (December 13, 2002), http://www.la-croix.com/Archives/2002-12-13/Que-valent-nos-valeursInterview-Rene-Girard-_NP_-2002-12-13-171969 (accessed August 25, 2017). For additional remarks on the mimetic rivalry between Jihad and the West see René Girard, Battling to the end (East Lansing: Michigan State University Press, 2010), 41; 211-212.

${ }^{5}$ Prior to the tragic attacks perpetrated by the Kouachi brothers on the $7^{\text {th }}$ January 2015 in the offices of Charlie Hebdo, the French satirical journal was nearly in a state of bankruptcy.

${ }^{6}$ Literally "Live together". Vivre-ensemble is a vague concept related to the idea of social harmony. In France, the expression vivre-ensemble is frequently used in political and media discourse.

${ }^{7}$ It is worth mentioning that the Hyperfestive cannot be reduced to a mere multiplication of festivals and parties (even if it can be considered as a symptom). According to Philippe Muray, the Hyperfestive refers to an unprecedented anthropological transformation that erases all the crucial differences (man/animal, private/public, masculine/feminine etc.) that made human History. In this way, the Hyperfeste is inseparable from a Post-Historical stage of which Homo festivus is the happy inhabitant. See, for instance, Philippe Muray, Le Portatif (Paris : Editions Mille et Une Nuits, 2006), 4250.
} 
this new post-attacks mysticism. They are the necessary hallucinations for the mediatic High Mass.

\section{"They will not change us."}

This is the response to the mimetic desire of jihadism. What was attacked is made sacred by the attack itself. Far from changing our way of life, the attacks reinforce it by giving it an extra and artificial touch of soul. Celebrating our way of life is now a moral imperative. The community starts to build religious imagery around all the potentialities of festivities [toutes les virtualités de la fête]. In this, terrorism ratifies the complete victory of the contemporary festivist-worship [culte festiviste]: it is its most providential cement. ${ }^{8}$

\section{“We will stay united."}

This is the nuclear core of the solemn and compassionate Mass, the necessary illusion of victim worship. We are not united but we will stay united. We hate ourselves as a nation but we will not cease loving our land as a playground: such is the great simulacrum produced by mass murder. At the time of the disintegration of nations, divided in every respect, jihadism acts as the impetus for the religion of multiculturalism by generating a parody of sacred union. The more the victim is guilty in the eyes of the jihadist (because his way of life is against the Sharia law), the more innocent it is in our eyes. In the age of self-hatred and of European's strong feelings of guilt, this scandal contributes to the setting-up of a singular, unifying mysticism that works like a divine surprise: by restoring faith in the Western Man and his values of festivity and universal love.

\section{"It has nothing to do with religion."}

Lately, Christophe Castaner, ${ }^{9}$ continuing a long tradition of semantic prudery and aiming to avoid the risk of verbal discrimination, said on French radio that he preferred the word assassins to that of Islamist terrorists. He said this because those criminals would have nothing to do with the religion they betrayed. This passion for blindness that typifies the contemporary man always reveals a structural truth: here, in the context of his mimetic rivalry with the Western enemy, the jihadist cannot monopolize the religious. ${ }^{10}$ Better still, it is a question of

\footnotetext{
${ }^{8}$ In his essay Chers Djihadistes... (Dear Jihadists...), Philippe Muray ironically speaks to the terrorists on behalf of Homo festivus. He writes, for example: "We westerners have already been in pain for some time to place the feast, where the hegemonic order that we intend to impose is materialized in jubilant ways (...), under the seal of the sacred. The disasters that you [the jihadists] provoked finally allow us to do it." Philippe Muray, Chers Djihadistes... (Paris : Editions Mille et Une Nuits, 2002), 52-53. Just like Girard, Muray seems to perceive a mimetic rivalry in the conflict opposing the Jihad to the West: "Your [jihadists] violence, even more and more mad and murderous, will not cease strengthening us by binding you, in a dialectical way, each time more closely to us." Ibid., 20. Only a few lines later Muray writes: "And if you [jihadists] want to be equal to the unprecedented situation you have created, you will have to imitate us." Ibid., 21.

${ }^{9}$ Christophe Castaner was Emmanuel Macron's spokesman during his presidential campaign and is now the French Government spokesman.

10 This exclusion of the religious dimension is also the target of Muray's irony: 'Your [jihadists'] religious reasons, which we cannot take into account, except to grant you precisely with reasons,
} 
excluding him from the sphere of the sacred. How? By seeking to deprive his discourse of all dogmatic content while at the same time invoking an idealized Islam- supposedly a pure religion of peace and love. Whatever theological veracity, the important thing is not learning to recognize Islamic terrorism but sanitizing it. Essentially, rapidly dissolve Islamic terrorism to maintain the religious sphere exclusively for the compassionate moments made of candles and teddy bears.

\section{"They are cowards."}

The suicide attack seeks to put into competition two conceptions of martyrdom: the former Islamist and warlike, the latter Western and victimized. In media imagery, the former must immediately be ruled out for the second to become sacralised. The suicide bombers are thus deprived of their own sacrifice (always being reduced to a state of near-dementia) to guarantee the exclusivity of the sphere of the sacred for the innocent victims whose martyrdom is portrayed in the form of a vague and parodic Christianity. For contrary to the Christian story in which the Saints enter freely into their passion, the religiosity of the passers-by who fell on the battlefield is of stunning nullity. It is a question of conferring a posthumous mission onto them by consecrating the scene of their death and thereby taking up their fictitious and sacred torch: We are terraces, We are airports, We are Paris, Nice, Manchester, or London.

Moreover, it is not uncommon for the media to produce some occasional heroes - one young man or another, preferably of foreign origin, having made a tourniquet for an injured person or having filmed the attack without shivering with fear. Soon other brave men will also step into the light by attending memorial concerts armed with a placard, a votive candle, or a solidary can of beer and joining the gigantic compassionate party like others joined the French resistance.

\section{"They will not have our hate."}

Since the only enemy of western nations - their sacred terror - is nothing but their own division, terrorists are never perceived as enemies being worthy of hatred. Consequently, the jihadist conveniently intervenes as a providential ally. Just as the lightning ends a state of atmospheric tension, the terror attack quells the collective violence of a nation that does not like itself anymore but that reunites it by dint of the sacrifice that struck it. Thus candles deify victims without ever causing society to run the risk of civil war through a call for revenge. As a matter of fact, as soon as it is immolated - as soon as it becomes sanctified the reunited nation, not giving in to discrimination, is adduced. There is no need to track down the assassins because they already joined their afterlife. As for the religious fanatics registered in police databases and likely to strike as well, they actually encounter no risk:

which would also amount to granting you humanity, will be lost in the mess of the amusement park of which we are the creators and which, little by little, overthrows all the rest." Ibid., 20. For Muray, this is not merely a matter of dehumanizing the enemy. The denial of the religious dimension of jihadism allows the West to deny its own nihilism by putting the blame on the terrorists. See ibid., 108-109. 
indeed, a nation in robust health would naturally have the right to demand their heads - but we do not do it, we content ourselves with paying tribute to our pious and pitiful victims without ever seeking redress. It must therefore be concluded that mass murder is a kind of sacred norm, which must at the same time make a mark on everyone's minds but without ever causing the escalation of proliferating violence. Besides, the random victims selected by the macabre "wrong place, wrong time" lottery enter the virtuous circle of our egalitarian cult.

\section{"We are on the side of life."}

But we never stop celebrating death. The affinities between festivism and mortifying cult no longer need to be demonstrated. Since Philippe Muray, we know that Homo festivus and Homo funestus are twin brothers. By this, mass murder reveals the profound meaning of our funerary end of civilisation. Mass murder is the never-ending pretext of a ritual and commemorative feast.

A collective, unavowable, and largely unconscious enjoyment seems to grip media consumers at the announce of a new attack. Evil struck the West so that the Feast might triumph again with greater fervor. "We are not afraid! We are not hurt?" pound out the pilgrims on the squares of our bruised cities, who flee like a flock of birds at the first sound of a child's firecracker. In addition to their infantilism, these phrases say a great deal about the mystical addiction that the attacks provoke. The stupefaction after the first attacks gave way to the sinister habituation and then to a nearly religious media addiction. A kind of delectation spreads over social networks. The dead and the wounded are counted with frenzy. The ritual, with its archaic fragrances, can begin. The sacrificers [sacrificateurs] have a sinister look and worship a black flag, but the protagonists of the great televised catharsis are young and impeccable journalists, bathed in light. The community regains the communion that has been lacking. In this respect, terrorism clinches the total victory of the contemporary West which made social harmony and group interaction its own religion. The attacks appear to be the most sacred events of our bored and dislocated societies. They are not only "Europe's ambient music" as states Alain Finkielkraut. They are on the way to becoming its highest Canticle.

\section{References}

Girard, René, Tincq, Henri. "What is Occuring Today Is a Mimetic Rivalry on a Planetary scale”. Initially published in Le Monde (November 6, 2001). Translated by Jim Williams for CO\&VR. https://www.uibk.ac.at/theol/cover/girard/le_monde_interview.html (accessed August 16, 2017).

. «Que Valent nos Valeurs?». La Croix (December 13, 2002). http://www.lacroix.com/Archives/2002-12-13/Que-valent-nos-valeurs-Interview-Rene-Girard_NP_-2002-12-13-171969 (Consulté le 25 août 2017)

Philippe. Chers djihadistes... . Paris: editions Mille et Une Nuits, 2002.

Muray, Philippe. Le Portatif. Paris: editions Mille et Une Nuits, 2006.

Essais. Paris: Les Belles Lettres, 2015. 